Debra Ziegeler

Converging Grammars 


\section{Language Contact and Bilingualism}

Editor

Yaron Matras

Volume 11 


\section{Debra Ziegeler \\ Converging \\ Grammars}

Constructions in Singapore English

DE GRUYTER

MOUTON 
ISBN 978-1-61451-571-5

e-ISBN (PDF) 978-1-61451-409-1

e-ISBN (EPUB) 978-1-5015-0063-3

ISSN 2190-698X

Library of Congress Cataloging-in-Publication data

A CIP catalog record for this book has been applied for at the Library of Congress.

Bibliographic information published by the Deutsche Nationalbibliothek

The Deutsche Nationalbibliothek lists this publication in the Deutsche Nationalbibliografie; detailed bibliographic data are available on the Internet at http://dnb.dnb.de.

(C) 2015 Walter de Gruyter GmbH, Berlin/Boston

Typesetting: Compuscript Ltd., Shannon, Ireland

Printing and binding: CPI Books GmbH, Leck

@ Printed on acid-free paper

Printed in Germany

www.degruyter.com 